\title{
Solar Energy Development and Social Sustainability: A Case Study on the Teknaf Solar Power Plant in Bangladesh
}

\author{
Zafrin Ahmed Liza ${ }^{1}$, Hajera AKtaR ${ }^{2}$ \\ AND MOHAMMAD RAKIBUL ISLAM ${ }^{3 *}$ \\ ${ }^{1}$ Department of Anthropology, Shahjalal University of Science and Technology (SUST), \\ Sylhet, Bangladesh \\ ${ }^{2}$ Department of Political Science, Shahjalal University of Science and Technology (SUST), \\ Sylhet, Bangladesh \\ ${ }^{3}$ Department of Electrical and Electronic Engineering, Islamic University of Technology (IUT), \\ Gazipur, Bangladesh
}

\begin{abstract}
Due to Bangladesh's rapid development and fast-growing economy, the Government has placed an emphasis on ensuring a reliable and quality supply of electricity, to permit sustainable and financial development. The state's policy on private sector involvement and the release of marginal lands for energy plantations is intended to enhance access to energy, through diversifying the energy supply. The country's first solar park, with a capacity of 28 megawatts (MW), was established on 116 acres of land in Knila, Teknaf of Cox's Bazar. This facility started producing electricity in September 2018, which is currently being added to the national grid. Solar power is one of the cleanest energy sources, but this does not guarantee that it will be sustainable for all societies. Sustainability is determined by three different parameters: environmental sustainability, social sustainability, and economic sustainability. This paper critically discusses the impact of the project on the socio-economic and agro-ecological conditions of the local people. Using the empirical research method, here the effects have been understood and analyzed from the perspective of the political economy.
\end{abstract}

Keywords: sustainable development, privatization, solar plant, renewable energy

\section{INTRODUCTION}

Bangladesh's power crisis is one the country's major problems. Day by day, the gap between demand and production is increasing. With a current population of 163.94 million people,

*Corresponding author: rakibultowhid@yahoo.com

Received: 16 Jan 2020 Accepted: 24 Feb 2020 Published: 23 Mar 2020

Journal of Asian Energy Studies (2020), Vol 4, 1-8, doi:10.24112/jaes.040001 
Bangladesh is facing an imminent energy crisis [1]. Electricity plays a great role wherever people live, and is also vital for sectors like industry, agriculture, transportation, etc. With the rapid advancement of technology, power consumption has also increased. An available and reliable source of electricity is considered a major prerequisite for sustained and successful economic development efforts and poverty reduction [2]. For Bangladesh to attain sustainable Gross Domestic Product (GDP) growth of 6\% and above until 2030 and beyond, it is necessary to meet these essential energy needs. The Government has taken many initiatives to enhance the reliable and quality supply of electricity, for sustainable and economic development. The Government's policy on private sector involvement, and the release of marginal lands for energy plantations, is intended to improve access to energy by diversifying the country's energy supply. With an intention to reduce the dependency on fossil fuels for electricity generation, the Government has initiated a plan to build grid-tied solar-based power generation projects in non-agricultural lands. The power generated from these solar parks will feed directly into the grid on a commercial basis. According to the Renewable Energy Master Database, the total renewable energy capacity, including all categories, is 2,273.09 megawatts (MW). Among these, solar park projects are the main contributors in terms of capacity, comprising 1,905.36 MW. As the Government is under the process of establishing more solar parks in the country, as part of sustainable development, now is the time to understand the impact of the project on the local community. Sustainability at the macro level might not have the same impact at the micro level [3]. A specific technology cannot be appropriate or sustainable because the concept of sustainability is ambiguous and situational.

In a country like Bangladesh, where the population density is high, and land is highly productive and demandable, is the solar plant project socially sustainable? There is no doubt that it will boost the country's economy, but we need to understand the socio-cultural and agro-ecological challenges.

\section{Electricity Generation In BANGLADESh}

Bangladesh uses different energy resources to produce electricity. The electricity generation composition is shown in Figure 1.

High-speed diesel (HSD) is used as a fuel in medium- and high-speed compression ignition engines in commercial vehicles. These engines operate at speeds above $750 \mathrm{rpm}$. HSD is also used in stationary diesel engines, locomotives, and pumps, etc. The diesel engine is a high compression and self-ignition engine, where the fuel is ignited by the heat of the high compression.

Heavy fuel oil (HFO) is based on the high viscosity, tar-like mass that remains after the refinement and subsequent cracking of crude oil when producing lighter hydrocarbon products such as petrol, distillate diesel fuels, heating oil, or feed stocks for lubricants. HFO power generators are suitable for harsh operating conditions. In the absence of grid power, they are the ideal cost-effective option to meet power needs quickly [4].

Renewable energy is collected from renewable resources, which are naturally replenished on a human timescale, such as sunlight, wind, rain, tides, waves, and geothermal heat. Hydroelectric power is also included in this section. A large amount of power in Bangladesh is generated from this source. The Karnafuli Hydroelectric Power Station is the only hydroelectric power station in Bangladesh; it generates $230 \mathrm{MW}$ of power.

A captive power plant is a facility that is dedicated to providing a localized source of power to an energy user. They are often used in industrial facilities or in large offices. These plants can operate in the grid parallel mode, with the ability to transfer surplus power to the local electricity grid. Alternatively, they may be able to operate in the island mode; i.e. independently of the local electricity grid. In places where there is a localized supply of gas, gas engines make ideal captive 
power plants. The supply of gas can be from a gas pipeline, or can be transported via vehicles as compressed natural gas (CNG) or liquefied natural gas (LNG) [5].

Coal fired power plants use the combustion of coal to generate electricity. Forty percent of the world's electricity is provided by coal, and they are primarily used in developing countries. Coal power plants have many associated environmental impacts on local ecosystems [6].

Gas is the largest energy source in Bangladesh. It comprises the largest portion due to its availability throughout the country. It is used in Bangladesh at different power stations in three main ways: oil - and gas-fired thermal, gas turbines, and gas engines.

Imported electricity is a substantial part of the energy combination of the total energy generation of Bangladesh. Bangladesh already imports $660 \mathrm{MW}$ of electricity from the neighboring country of India. Honorable Prime Minister Sheikh Hasina expressed her hope that India will help Bangladesh to implement her plan to import 9,000 MW of electricity from neighboring countries by 2041 [7].

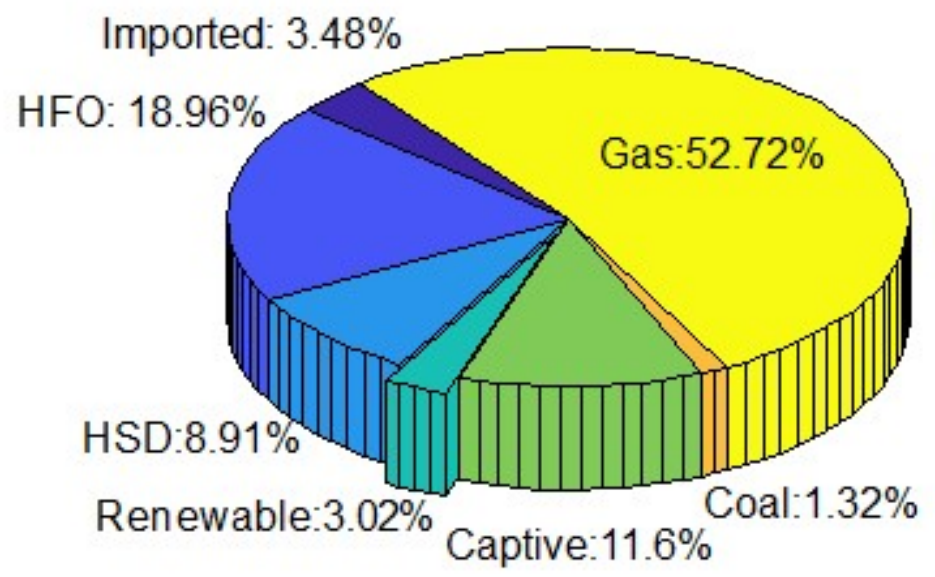

Figure 1: Electricity Generation in Bangladesh; HFO = Heavy Fuel Oil, HSD = High-Speed Diesel

\section{Use of Solar Energy in Bangladesh}

Solar energy comprises radiant light and heat from the sun that is harnessed using photovoltaic cells, solar thermal energy, solar heating, molten salt power plants, or artificial photosynthesis. Solar energy is a free source of energy that is both inexhaustible and sustainable; thus, it is renewable. Solar panels are able to extract energy from the sun and transform it into electricity. Another advantage of solar energy is its non-polluting nature, as it does not emit any greenhouse gases while producing electricity. Therefore, the use of these solar panels is environmentally friendly.

Among all of the renewable energy resource potentials in Bangladesh, solar energy appears to have the greatest potential. Solar radiation varies from $3.8 \mathrm{kWh} / \mathrm{m}^{2} /$ day to $6.4 \mathrm{kWh} / \mathrm{m}^{2} /$ day, with an average of $5 \mathrm{kWh} / \mathrm{m}^{2} /$ day. The photovoltaic electricity potential is shown in Figure 2 . 


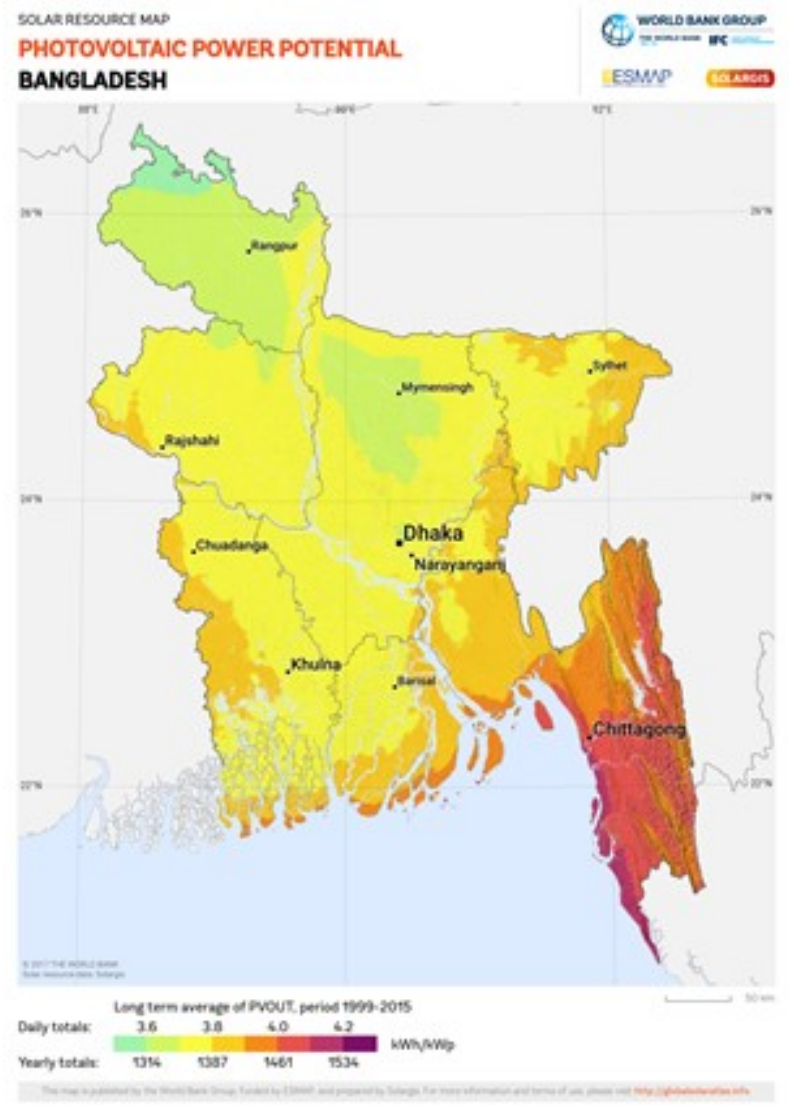

Figure 2: Photovoltaic Electricity Potential for Bangladesh [8]

\section{Solar PARK IN TeKNaF}

Bangladesh's first solar park has the capacity to produce $28 \mathrm{MW}$ of power, and will feed $20 \mathrm{MW}$ to its local substation during sunlight hours. It has been established on 116 acres of land in Teknaf, in Cox's Bazar district, and has started producing electricity, which is being added to the national grid. The power plant has been installed by a private organization, Joules Power Limited (JPL), with the help of an England-based firm, Promisor. Figure 3 shows the first large PV power plant in Teknaf, Chittagong, Bangladesh. It is located on the east side of the Cox's Bazar-Teknaf highway. Some 87,500 (total installed capacity 27.69 MW) solar panels have been installed on the bank of the Naf River, in the border area of Bangladesh and Myanmar, where salt and shrimp were rotationally cultivated earlier. Now, solar power is being generated at this location, which should benefit electricity users in Teknaf and Ukhiyaupazila of Cox's Bazar. It is expected that up to $80 \%$ of the total electricity demand of the two upazila will be fulfilled by the power plant. Bangladesh has a long legacy in the field of renewable energy, which started back in 1957 with the construction of the country's first hydroelectric project on the Karnaphully River at Kaptai, Chittagong. Due to negligence, regarding the project's effect on local communities, the earlier energy project of the Kaptai had a high social cost. One of the Government' major goals is to bring sustainable development to the country, and for this, it is important to understand the social impact of any related project among local people. The solar park is a new intervention in 
Bangladesh, and this paper critically discusses the socio-economic impact of the project from an anthropological perspective.

The plant has five sub-stations each surrounded by panels. The power generated by these panels is primarily stored at the facility, and is then later transmitted to the substation of Palli Bidyut, located in the Leda area of the Hinla union. The solar PV plant will cover up to 80 percent of the present electricity demand of the entire Teknaf region, resulting in a reduction in $\mathrm{CO}_{2}$ emissions of 20,000 tons per year, with an estimated 400,000 tons of carbon dioxide emissions expected to be prevented over the next 20 years. Table 1 summarizes the $28 \mathrm{MW}$ power station's specifications.

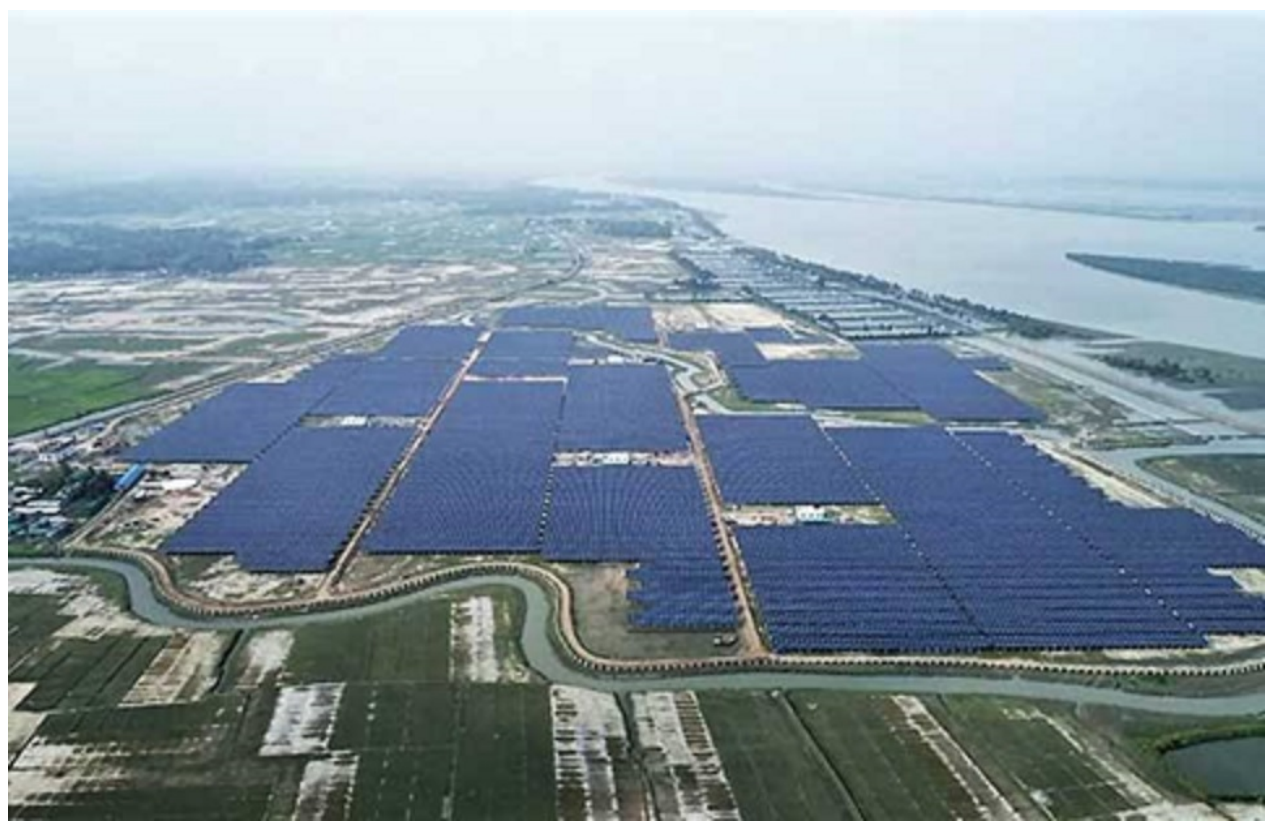

Figure 3: Bangladesh's first larger PV power plant in Teknaf

Table 1: 28 MW Power Station Specifications

\begin{tabular}{|c|c|c|}
\hline Item & $\begin{array}{l}\text { Quan- } \\
\text { tity }\end{array}$ & Status \\
\hline Inverter & 1 & Inverter is connected with a step-up \\
\hline MPPT & 2 & Two MPPT charge controllers are connected inside a single inverter \\
\hline $\begin{array}{l}\text { DC combiner } \\
\text { box }\end{array}$ & 16 & $\begin{array}{l}\text { Eight DC combiner boxes are connected with a single MPPT charge } \\
\text { controller }\end{array}$ \\
\hline PV module & 7056 & $\begin{array}{l}(21 \times 21)=441 \text { modules are connected in SP configuration with a } \\
\text { single DC combiner box }\end{array}$ \\
\hline
\end{tabular}

\section{Methodology}

The aim of this qualitative research study is to understand the impact of the privatized renewable energy plant on the socio-economic and agro-ecological conditions of local people. The qualitative 
study was carried out in Knila, Teknaf. Four focus group discussions were conducted with the local people (salt farmers, salt distributors, salt transporters, beggars, local shopkeepers, rickshaw pullers, and CNG drivers) and stakeholders (guards of the project, local NGO workers, and local service holders) to develop our initial understanding of the solar plant project. To determine an in-depth idea of the problem, we conducted seven in-depth interviews with local people. Key informant interviews were also conducted with two community leaders and three people who had lost land. The collected data were sorted and analyzed to understand the situation. Secondary data sources were also used.

\section{DiscusSION AND ANALYSIS}

The many advantages of the solar park are well known, but its disadvantages also need to be considered. Our argument is not that solar energy is flawed, rather we want to recall E. F. Schumacher's warning that technology cannot solve all of our problems, especially in the domain of a profit-based economy; Schumacher instead advocated for the use of "appropriate technology" [9]. When we think about appropriate technology, we must think locally, and consider its impact on the local community.

The major drawback of implanting large-scale solar plants in overpopulated countries such as Bangladesh is the necessity for the requisition of huge areas of land. Bangladesh has the tenth highest population densities in the world (1,115.62 people per square kilometer) [10]. This large population is dependent on a limited area, resulting in problems relating to food, shelter, and health. This type of energy production is a serious concern for a land-scarce country like Bangladesh, as it will create extra pressure on the land, as the technology is land intensive. Moreover, 910,000 Rohingya refugees have taken shelter in Cox's Bazar, Teknaf, and surrounding areas, from bordering Myanmar [11].

Government policy stated that the solar power plant should be established on unproductive land, but due to its geographical location, the land is highly productive and valuable. Its value is not necessarily linked to the market, but to the environment. This project was set up on 116 acres of land that were used in rotation: for salt cultivation during the dry season, and for shrimp farming during the rainy season. Both salt and shrimp cultivation are labor-intensive processes, and are the major source of income for local inhabitants. A study has shown that every year the country loses $1 \%$ of its farmland to non-agricultural uses. This process is especially affecting poor people, who are therefore becoming more vulnerable to food insecurity [12]. The private company leased the land from the owners without consulting with the farmers. The landowners of the area were a group who were not involved directly with cultivation, rather their income came from the leases. This landowner group, who were basically the owners of the capital, always intended to maximize their profit, so they leased their land to private companies at a higher price. Even local people who were directly or indirectly dependent on the land were not informed about the park. Newspaper reports stated that, in Mymensingh, people protested against land acquisition for the solar park. After this, however, it was established at Teknaf, without consulting the local people.

The local economy of the area is mainly based on salt production and fishing. Approximately one hundred salt cultivators were directly dependent on the land that was rented for the project, and almost one hundred and fifty people were indirectly involved as land laborers, transporters, traders, and input suppliers. Due to this solar project, therefore, almost 250 people lost their jobs, which would have economically affected a larger group, when considering their family members. This unemployment also affected the business of other small local vendors. Only a very small number of these people have re-established themselves in local small business and service sectors; a large number of them remain unemployed. There was no alternative arrangement, nor was any 
compensation provided. Furthermore, although with much hardship the local men who were affected could have managed somehow to make their livelihoods in the adjacent areas, but women, as an especially vulnerable group, became marginalized abruptly. This unemployment has had a significant effect on their families. Our investigation found that among the respondents, four families had withdrawn their children from the school, and had sent them out to beg or work small jobs. Six families stated that they could provide one-time meals to family members. In particular, younger and elderly family members were reported to be suffering from malnutrition.

The project itself did not create a significant number of job opportunities for local inhabitants. Depending on the daily demand, fifteen to thirty people were hired by the project as casual workers. Our respondents informed that Rohingya refugees were preferentially employed for this daily labor, as they were willing to work illegally for cheaper wages. Due to language barriers and community cohesion, they were unwilling to migrate, and admitted that many of the community members had become involved in illegal (Yaba) drug smuggling from Myanmar, hefting, robbing, and begging. The availability of Yaba has become one of the major threats for the young generation throughout the country, who have become addicted to it. One of the elderly men said: "we know that drug peddling is bad, but we do not have any other choice to earn money. It is not us, but the Government policy, that is forcing us to do bad things." During our focus group discussion, respondents mentioned that drug peddling and consumption had increased even after the Government had declared war against Yaba, and had expressed their concern about increasing offences.

It was assumed that the park would supply 80 percent of the local energy demand, but in reality the situation is different. During our fieldwork, we noticed that community people were facing long hours of load sharing every day, even after the full production of the plant. The electricity produced was being transmitted to the national grid to support the economic growth of other areas, rather than remaining in the local community, which was in a marginal situation. The Government plans to establish an economic zone in Teknaf, which will create employment opportunities for the local people. Thus, the country's economic growth depends on the sacrifice of poor farmers' cultivable land, and had resulted in their financial hardship.

The park area is surrounded by a boundary wall that restricts access to people. This boundary wall has segmented the area, and has disturbed the harmony of the previous cultivation. Our respondents also mentioned that there was a public road within the project area, which had been blocked and restricted for the people of the local community. This road closure had a complex impact on their agro-ecological and economic life. The road was important to the people as it provided the inhabitants and their livestock access to the Naf River. Water sources are important for their cultivation. Fishing at the Naf River was also an alternative source of earnings.

The Government is trying to solve the country's electricity problem by involving the private sector, which was part of their election mandate. The production of solar panels requires capitalintensive manufacturing facilities that are highly automated. At present, Bangladesh is unable to manufacture the required PV modules, and these were thus imported from outside countries [13]. The government is paying 0.17 US\$ per unit, which is much higher than their retail price. If we compare this price with neighboring India, we can see that the state-run Solar Energy Corporation of India (SECI) managed to produce solar energy for 0.00036 US\$ (Rs 2.44) per kilowatt-hour $(\mathrm{kWh})$ [14]. The situation raised the question of why the government is buying electricity at such a higher price, especially when the cost of producing solar power is rapidly declines. We need to consider who is selling this technology, who is managing it, and who is taking advantage of it. As Schmidt (1993) stated, "State activity is derived from the interests of social classes, their organizations, and the institutional condition for government of the distribution of conflicts, as well as the strategic maneuvering of the governing elite." This high price has meant that the 
advantage of the energy will be enjoyed only by a special group of people. At the same time, the study observed discrimination in the distribution of power.

\section{Conclusion}

Privatization has become a unique characteristic of global political, economic, and social transformations. Bangladesh's government has also surrendered a greater part of its material wealth and responsibilities to the private sector. The State's policy on private sector involvement and the release of marginal lands for energy plants is intended to enhance access to clean energy for sustainable development. However, the situation raised questions regarding whose development has been considered. Sustainable development concerns not only economic or environmental sustainability, but also the social sustainability of marginal, poor people. This solar plant will accelerate the country's economic growth, but it has failed to create opportunities for the poor landless farmers, and has instead destabilized their social consistency. As Bangladesh's government plans to establish several further solar energy parks, it is critical that thought is no given to their appropriateness. Should we proceed with such land intensive and costly energy production methods, or do we need to search for a better alternative?

\section{REFERENCES}

[1] Worldometers, April 2019. http://www.worldometers.info/world-population/\#top20 [Accessed on 16-01-2020].

[2] Haque M, Rahman J. Power Crisis and Solution in Bangladesh. Bangladesh Journal of Scientific and Industrial Research 2010:45:155-162.

[3] Kattel S. Sustainability or sustainable development: An anthropological perspective. Occasional Papers in Sociology and Anthropology 2005:9:258-277.

[4] https://www.aggreko.com [Accessed on 03-04-2019].

[5] https://www.clarke-energy.com/captive-power-plants/ [Accessed on 08-01-2020].

[6] World Coal Association. Coal and Electricity. http://www.worldcoal.org/coal/uses-ofcoal/coal-electricity/ [Accessed on 11-01-2020].

[7] https://www.dhakatribune.com/bangladesh/power-energy/2018/09/10/india-begins500mw-additional-power-supply-to-bangladesh [Accessed on 05-04-2019].

[8] https://globalsolaratlas.info/ [Accessed on 12-01-2020].

[9] Schumacher EF. Small is Beautiful: Economics as if People Mattered. Harper \& Row, New York, 1973.

[10] World Population Review 2019. http://worldpopulationreview.com/countries/bangladeshpopulation/.

[11] UNICEF, Rohingya Crisis. https://www.unicef.org/emergencies/rohingya-crisis.

[12] Quasem MA. Conversion of agricultural land to non-agricultural uses in Bangladesh: Extent and determinants. Bangladesh Development Studies 2011:34:59-85.

[13] Mondal MAH, Sadrul Islam AKM. Potential and viability of grid-connected solar PV system in Bangladesh. Renewable Energy 2011:36:1869-1874.

[14] Berkey J. One simple chart shows why an energy revolution is coming and who is likely to come out on top. textitBusiness Insider https://www.businessinsider.com/solar-power-costdecrease-2018-5

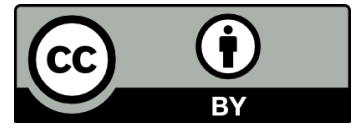

(C) The Author(s) 2020. This article is published under a Creative Commons Attribution (CC-BY) 4.0 International License. 